\title{
Mites associated to Xylopia aromatica (Lam.) Mart. (Annonaceae) in urban and rural fragments of semidecidual forest
}

\author{
Felipe M. Nuvoloni ${ }^{1}$, Reinaldo J. F. Feres ${ }^{2} \&$ Peterson R. Demite $^{1}$
}

'Programa de Pós-graduação, Biologia Animal, Universidade Estadual Paulista, 15054-000 São José do Rio Preto-SP, Brasil. felipe_nuvoloni@hotmail.com,peterson_demite@yahoo.com.br

${ }^{2}$ Departamento de Zoologia e Botânica, Universidade Estadual Paulista, Rua Cristóvão Colombo, 2265, Jardim Nazareth, 15054-000 São José do Rio Preto-SP, Brasil. reinaldo@ibilce.unesp.br. CNPq fellow.

\begin{abstract}
Mites associated to Xylopia aromatica (Lam.) Mart. (Annonaceae) in urban and rural fragments of semidecidual forest. Native plants can shelter a great diversity of mites. Notwithstanding, the conservation of the forest fragments where the plants are located can influence the structure of the mites community. Generally, in homogenous environments the diversity is lower due to the dominance of one or a few species. In this work, we studied the mite community on Xylopia aromatica (Lam.) Mart. (Annonaceae) in two fragments of semidecidual forest: one on rural and other on urban area. Seven individuals of $X$. aromatica were monthly sampled from April 2007 to March 2008, in each of these fragments. Descriptive indexes of diversity, dominance and evenness were applied to verify the ecological patterns of the mite community, besides the Student's t-test to compare the abundance between the fragments. We collected 27,365 mites of 37 species belonging to 11 families. Calacarus sp. (Eriophyidae) was the most abundant species, representing $73 \%$ of the total sampled. The abundance was greater in the urban fragment $(67.7 \%)$, with the diversity index reaching only $25 \%$ of the theoretical maximum expected. Probably, these values might have been influenced by the location of this fragment in the urban area, being more homogeneous and submitted directly to the presence of atmospheric pollution. In this manner, $X$. aromatica is able to shelter a higher diversity of mites when inserted in preserved ecosystems, since the highest diversity of available resources allows the establishment of richer and most diverse mite community.
\end{abstract}

KEYWORDS. Mite fauna; native plants; preservation; seasonality; urban impact.

RESUMO. Ácaros associados a Xylopia aromatica (Lam.) Mart. (Annonaceae) em fragmentos urbano e rural de floresta estacional semidecidual. Plantas nativas podem abrigar uma grande diversidade de ácaros, entretanto o estado de conservação dos fragmentos onde estas plantas estão localizadas pode influenciar a estrutura da comunidade. Em ambientes homogêneos a diversidade geralmente é menor devido à dominância de uma ou poucas espécies. O objetivo deste trabalho foi conhecer a acarofauna associada a Xylopia aromatica (Lam.) Mart. (Annonaceae) em dois fragmentos de floresta estacional semidecidual, sendo um rural e outro urbano. Amostramos mensalmente no período de abril de 2007 a março de 2008, sete indivíduos de X. aromatica em cada um dos dois fragmentos. Índices descritores de diversidade, dominância e de equitabilidade foram aplicados para verificar os padrões ecológicos da comunidade, além do Teste $t$ de Student para comparar a abundância de ácaros entre os fragmentos. Foram coletados 27.365 ácaros de 37 espécies pertencentes a 11 famílias. Calacarus sp. (Eriophyidae) foi a espécie mais abundante, representando $73 \%$ do total amostrado. A abundância total foi maior no fragmento urbano (67,7\%), com a diversidade atingindo somente $25 \%$ da máxima teórica prevista. Provavelmente, estes valores foram influenciados pela localização deste fragmento na área urbana, sendo mais homogêneo e submetido à presença de poluentes atmosféricos. Dessa forma, $X$. aromatica pode abrigar uma maior diversidade de ácaros quando inserida em um ecossistema conservado, visto que a maior diversidade de recursos disponíveis permite o estabelecimento de uma acarofauna mais rica e diversa.

PALAVRAS-CHAVE. Acarofauna; conservação; impacto urbano; planta nativa; sazonalidade

Remnants of forested fragments of São Paulo State correspond to small areas, isolated and under intense anthropic action, which are characterized by being very vulnerable and intensely impacted (Viana \& Pinheiro 1998). The northwestern region of the São Paulo State has only $3.3 \%$ of native vegetation remaining, considering that through the 1990's, these region lost more than 16 thousands hectares of natural vegetation, composed mainly by the semidecidual forest and spots of Cerrado lato sensu (SMA/IF 2005). This is the most deforested and fragmented region of this State and with the least concentration of preservation units (Kronka et al. 1993). Furthermore, the fragments are generally found near cities and highways (Viana \& Pinheiro 1998) with high levels of air pollution as a result of anthropic activities.
Native plants can contribute for the agricultural pest control, sheltering predator mites and entomopathogenic microorganisms (Altieri et al. 2003). Demite \& Feres (2005, 2008) observed that fragments of native vegetation closer to monocultures could provide shelter for predator mites that move to adjacent areas searching for alternative food and refuge. On the same way, Feres et al. (2007), Daud \& Feres (2005) and Feres et al. (2003), verified the ecological pattern and population dynamics of the community of mites in fragments of native plants of semidecidual forest, listing vegetal species able to shelter, offer alternative food and serve as refuge for some mites species.

Xylopia aromatica (Lam.) Mart (Annonaceae) is found in Cerrado and Semidecidual Forests areas in the States of São 
Paulo and Minas Gerais (Miranda-Mello et al. 2007). The plant has medium height reaching from 4 to 6 meters high and blooming twice a year, with greater intensity starting in November (Lorenzi 2000). In spite of being a common vegetal species in the northwest region of the State of São Paulo, no studies were made to verify the structure of the mite community associated to this tree. Thus, we analyzed the structure and seasonality of the mites community associated to $X$. aromatica on urban and rural areas from São José do Rio Preto, SP. In this manner, the objective of this work was to evaluate the possible influence of the localization of the fragments on the community of mites associated.

\section{MATERIAL AND METHODS}

Study area and sampled data. Two fragments of semidecidual forests were taken as samples: one located in the urban perimeter $\left(20^{\circ} 46^{\prime} \mathrm{S} 49^{\circ} 21^{\prime} \mathrm{W}-30 \mathrm{ha}\right)$ and another, in rural area $\left(20^{\circ} 46^{\prime} \mathrm{S} 49^{\circ} 19^{\prime} \mathrm{W}-45 \mathrm{ha}\right)$, faraway about four kilometers from one another, in the São José do Rio Preto, State of São Paulo. The climate of this region is tropical hot and humid (Cwa-Aw, according to Köpen classification), characterized by a hot and humid season in the summer and another with dry weather in winter. Every year the rainy season (October to March) starts at variable dates and receives $85 \%$ of the annual rainfall, whereas the cold and dry season (April to September) receives only 15\% (Rossa-Feres \& Jim $2001)$, that varies from 1,100 to $1,250 \mathrm{~mm}( \pm 225 \mathrm{~mm})$ (Barcha \& Arid 1971).

The urban fragment is situated near to residential areas, an avenue and a stretch of the highway BR-153 (Transbrasiliana Highway), with several trails in its interior. The rural fragment is limited by a pasture area, rubber-tree woods, sugar-cane plantations, and one of its borders are near to a reforestation area with regional native plants, implanted four years before the start of the samples.

Previously to the study, seven individuals of $X$. aromatica were selected and marked in each area. In the urban fragment, were sampled trees localized in the border close to the BR-153, while in the rural fragment area, plants in the border close to the reforestation area were used.

The collections were monthly and executed during the period from April 2007 to March 2008. In each sampled, we collected 10 leaves randomly around the crown of the marked trees, up to a height of 5 to 6 meters, on a total of 70 leaves per fragment. Mites were collected from leaves by visual examination under a dissecting microscope, and were preserved in Hoyer's medium on glass slides, dried on a hot plate, ringed with nail polish and studied under a phase-contrast microscope.

Faunal Analyses. The diversity and the evenness of the mite fauna were analyzed by the Shannon-Wiener (H') and Pielou (e) indexes, respectively (Magurran 1988). The maximum theoretical diversity (H'max) was determinate according to Krebs (1999). The existence of dominance in the abundance of species was verified through a graphic analy- sis, by developing Curves of the Dominance Components (Odum 1988). The adjustment of the curve and the calculations of the ecological indexes were performed using the BioDiversity Pro 2.0 software (McAleece et al. 1997). The abundance of mites in each fragment was compared by Student's t-test, at level 5\% of significance (Zar 1999). To estimate the effect of the urban fragment over some species, we used the following formula $\ln R=$ In (e/c) (Olkin 1995); whereas $e$ correspond to the abundance of a determinate species in the urban fragment and $c$ to the abundance of the same species in the rural fragment. The Sperman's correlation test (rs) was used to verify the relation between the mite abundance to the floral period and monthly precipitation.

Constancy was calculated according to Silveira-Neto et al. (1976) and the species were classified according to their frequency in the samples in: frequent $(\mathrm{C}>50 \%)$, accessory $(25<\mathrm{C}<50 \%)$ and rare $(\mathrm{C}<25 \%)$.

According to feeding habits of each species, they were classified in four groups: Predators (Pr), formed by predator species and generalist predators; Phytophagous (Ph); Mycophagous (My); and species with unknown or uncertain feeding habits (?).

Climatic parameters data were obtained from CATI (Coordenadoria de Assistência Técnica Integral) in São José do Rio Preto, SP.

\section{RESULTS}

Were collected 27,365 mites on $X$. aromatica, belonging to 37 species distributed in 11 families (Tables I and II). Of that total, 27 species were common to both fragments, eight of these species were collected exclusively of the rural fragment and only two being exclusively of the urban one (Fig. 1).

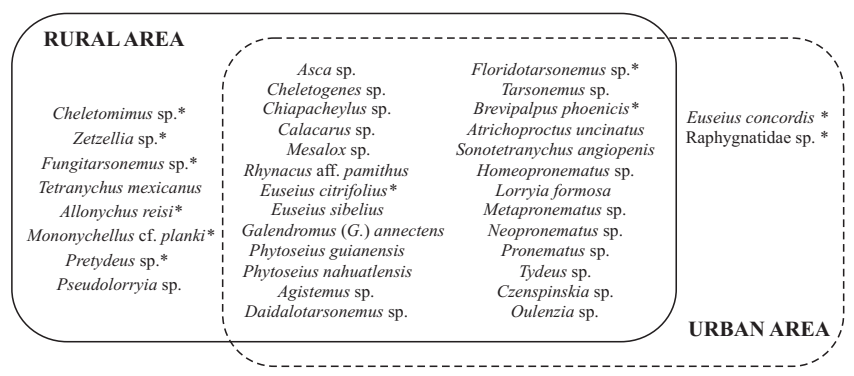

Fig. 1. Mites species registered in the rural and urban fragment of a Semidecidual Forest, in São José do Rio Preto from April 2007 to March 2008. *Rare species.

In both fragments predator mites constituted the greatest part of the species $(50 \%)$, whereas the phytophagous and mycophagous corresponded to $32.3 \%$ and $17.7 \%$, respectively. However, the phytophagous were more abundant in relation to the others ( $73 \%$ of the total mites sampled).

In the urban fragment, 14,736 mites were collected, distributed in 29 species. Among them, Calacarus sp. was the most abundant, with 11,387 individuals, followed by 
Table I. Monthly abundance of mites registered in the urban fragment in the period between April 2007 and March 2008.

\begin{tabular}{|c|c|c|c|c|c|c|c|c|c|c|c|c|c|c|c|}
\hline Family & Species & Apr & May & Jun & Jul & Aug & Sep & Oct & Nov & Dec & Jan & Feb & Mar & Total & Freq \\
\hline Ascidae & Asca sp. ${ }^{\mathrm{Pr}}$ & 0 & 0 & 1 & 0 & 0 & 0 & 0 & 0 & 0 & 0 & 0 & 3 & 4 & Rare \\
\hline \multirow[t]{2}{*}{ Cheyletidae } & Cheletogenes sp. ${ }^{\mathrm{Pr}}$ & 2 & 0 & 0 & 2 & 0 & 0 & 0 & 0 & 0 & 0 & 5 & 2 & 11 & Acess \\
\hline & Chiapacheylus sp. ${ }^{\mathrm{Pr}}$ & 12 & 2 & 10 & 3 & 3 & 0 & 1 & 0 & 0 & 0 & 0 & 0 & 31 & Acess \\
\hline \multirow[t]{2}{*}{ Eriophyidae } & Calacarus sp. ${ }^{\mathrm{Ph}}$ & 740 & 1317 & 2094 & 150 & 1290 & 366 & 106 & 91 & 345 & 584 & 1623 & 1326 & 11387 & Const \\
\hline & Mesalox sp. ${ }^{\mathrm{Ph}}$ & 0 & 0 & 0 & 0 & 0 & 0 & 0 & 0 & 0 & 0 & 207 & 29 & 236 & Rare \\
\hline Diptilomiopidae & Rhynacus aff. pamithus ${ }^{\mathrm{Ph}}$ & 5 & 62 & 31 & 15 & 56 & 0 & 0 & 0 & 0 & 89 & 40 & 36 & 334 & Const \\
\hline \multirow[t]{5}{*}{ Iolinidae } & Homeopronematus sp. ${ }^{\mathrm{Pr}}$ & 0 & 0 & 0 & 0 & 0 & 0 & 0 & 0 & 9 & 31 & 22 & 23 & 85 & Acess \\
\hline & Metapronematus sp. ${ }^{\mathrm{Pr}} ?$ & 0 & 0 & 0 & 0 & 0 & 0 & 0 & 0 & 12 & 6 & 18 & 6 & 42 & Acess \\
\hline & Neopronematus sp. ${ }^{\mathrm{Pr} ?}$ & 4 & 40 & 3 & 0 & 1 & 2 & 0 & 2 & 6 & 7 & 8 & 18 & 91 & Const \\
\hline & Parapronematus sp. ${ }^{\mathrm{Pr} ?}$ & 1 & 3 & 0 & 0 & 2 & 0 & 0 & 0 & 0 & 1 & 0 & 5 & 12 & Acess \\
\hline & Pronematus sp. ${ }^{\mathrm{Pr} ?}$ & 28 & 105 & 20 & 15 & 12 & 69 & 77 & 60 & 62 & 130 & 166 & 83 & 827 & Const \\
\hline \multirow[t]{6}{*}{ Phytoseiidae } & Euseius citrifolius ${ }^{\mathrm{Pr}}$ & 0 & 0 & 1 & 0 & 0 & 0 & 0 & 0 & 0 & 0 & 0 & 0 & 1 & Rare \\
\hline & Euseius concordis ${ }^{\mathrm{Pr}}$ & 0 & 0 & 0 & 0 & 0 & 0 & 0 & 1 & 0 & 0 & 0 & 0 & 1 & Rare \\
\hline & Euseius sibelius ${ }^{\operatorname{Pr}}$ & 7 & 34 & 21 & 24 & 1 & 0 & 10 & 21 & 25 & 28 & 27 & 26 & 224 & Const \\
\hline & Galendromus $(G$.$) annectens { }^{\operatorname{Pr}}$ & 0 & 6 & 0 & 1 & 0 & 0 & 0 & 0 & 0 & 0 & 2 & 6 & 15 & Acess \\
\hline & Phytoseius guianensis ${ }^{\mathrm{Pr}}$ & 3 & 0 & 0 & 0 & 0 & 0 & 0 & 0 & 0 & 2 & 9 & 8 & 22 & Acess \\
\hline & Phytoseius nahuatlensis ${ }^{\mathrm{Pr}}$ & 105 & 132 & 123 & 110 & 39 & 5 & 0 & 3 & 5 & 14 & 44 & 94 & 674 & Const \\
\hline Raphignatidae & Imature $\operatorname{Pr}$ & 0 & 0 & 0 & 0 & 0 & 0 & 0 & 0 & 0 & 1 & 0 & 0 & 1 & Rare \\
\hline Stigmaeidae & Agistemus sp. ${ }^{\mathrm{Pr}}$ & 2 & 10 & 1 & 0 & 0 & 0 & 2 & 0 & 0 & 11 & 0 & 29 & 55 & Acess \\
\hline \multirow[t]{4}{*}{ Tarsonemidae } & Daidalotarsonemus sp. ${ }^{\mathrm{My}}$ & 1 & 1 & 0 & 0 & 0 & 0 & 0 & 0 & 0 & 1 & 0 & 3 & 6 & Acess \\
\hline & Imature ? & 1 & 0 & 0 & 0 & 0 & 0 & 0 & 0 & 0 & 0 & 1 & 0 & 2 & Rare \\
\hline & Floridotarsonemus sp. ${ }^{\mathrm{My}}$ ? & 0 & 0 & 0 & 0 & 0 & 0 & 0 & 0 & 0 & 0 & 2 & 0 & 2 & Rare \\
\hline & Tarsonemus sp. My? & 4 & 2 & 0 & 0 & 0 & 0 & 0 & 0 & 0 & 0 & 13 & 47 & 66 & Acess \\
\hline Tenuipalpidae & Brevipalpus phoenicis $^{\mathrm{Ph}}$ & 0 & 0 & 0 & 0 & 0 & 0 & 0 & 0 & 0 & 0 & 0 & 2 & 2 & Rare \\
\hline \multirow[t]{2}{*}{ Tetranychidae } & Atrichoproctus uncinatus ${ }^{\mathrm{Ph}}$ & 0 & 2 & 0 & 16 & 2 & 17 & 51 & 41 & 54 & 23 & 8 & 0 & 214 & Const \\
\hline & Sonotetranychus angiopenis ${ }^{\mathrm{Ph}}$ & 1 & 32 & 0 & 5 & 3 & 0 & 70 & 8 & 0 & 13 & 29 & 0 & 161 & Const \\
\hline \multirow[t]{2}{*}{ Tydeidae } & Lorryia formosa $^{\mathrm{Ph} ?}$ & 6 & 16 & 4 & 23 & 30 & 0 & 0 & 0 & 0 & 0 & 0 & 2 & 81 & Acess \\
\hline & Tydeus sp. ${ }^{\mathrm{Ph} ?}$ & 0 & 0 & 12 & 44 & 9 & 3 & 0 & 0 & 0 & 0 & 0 & 0 & 68 & Acess \\
\hline \multirow[t]{2}{*}{ Winterschimidtiidae } & Czenspinskia sp. My? & 1 & 5 & 0 & 4 & 0 & 0 & 0 & 0 & 0 & 0 & 0 & 25 & 35 & Acess \\
\hline & Oulenzia sp. My? & 0 & 23 & 5 & 3 & 0 & 0 & 0 & 0 & 0 & 0 & 0 & 12 & 43 & Acess \\
\hline Total & & 923 & 1792 & 2326 & 1770 & 1448 & 462 & 317 & 227 & 518 & 941 & 2224 & 1785 & 14733 & \\
\hline
\end{tabular}

Feed habit: (Pr) Predators and generalist predators (Krantz 1978; McMurtry \& Croft 1997), (Ph) Phytophagous (Jeppson et al. 1975; Flechtmann 1975), (My) Mycophagous, (?) Feed habit unknown (Lindquist 1986; Krantz 1978; Gerson 1968 and Baker 1965).

Pronematus sp. (Iolinidae) and Phytoseius nahuatlensis (De Leon) (Phytosiidae), with 814 and 674 individuals, respectively. In the rural fragment were collected 12,629 mites belonging to 35 species. Calacarus sp. (Eriophyidae), with 8,562 specimens and Pronematus sp. with 1,062 were the most abundant too, followed by Rhynacus aff. pamithus (Diptilomiopidae) with 606 mites.

The abundance of predators was similar for both areas, reaching 2,189 individuals in the rural fragment and 2,094 in the urban. But, when considering only the dry period (from May to October), when was registered a very low pluviometric precipitation index (Fig. 2), the most common predatory mites, Pronematus sp. was twice more abundant in the rural fragment than in urban one $(\mathrm{t}=2.495 ; \mathrm{p}=0.028)$.

Moreover, in the dry period, the abundance of Calacarus sp. were about three times higher in the urban fragment than

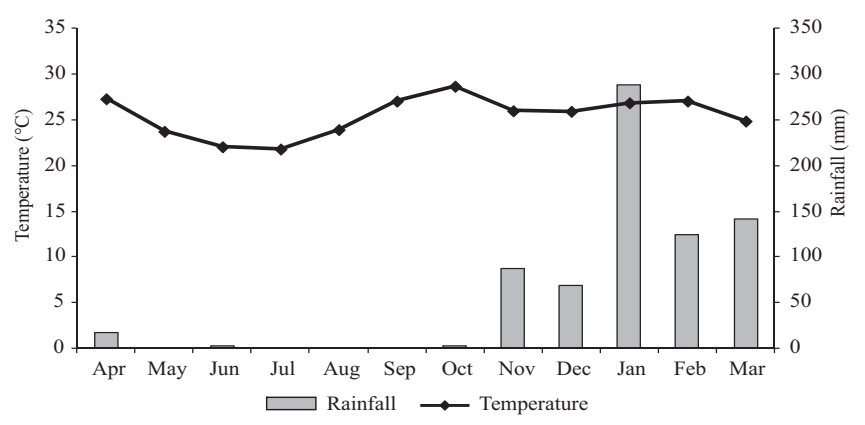

Fig. 2. Climatic parameters registered from April 2007 to March 2008 in São José do Rio Preto, SP.

the rural $(\mathrm{t}=2.387 ; \mathrm{p}=0.017)$. In this period, the urban fragment affected positively the abundance of Calacarus sp., and negatively the population of Pronematus sp. (Fig. 3). In the 
Table II. Monthly abundance of mites registered in the rural fragment in the period between April 2007 and March 2008.

\begin{tabular}{|c|c|c|c|c|c|c|c|c|c|c|c|c|c|c|c|}
\hline Family & Species & Apr & May & Jun & Jul & Aug & Sep & Oct & Nov & Dec & Jan & Feb & Mar & Total & Freq \\
\hline Ascidae & Asca sp. ${ }^{\mathrm{Pr}}$ & 0 & 1 & 0 & 0 & 0 & 0 & 0 & 0 & 0 & 0 & 1 & 1 & 3 & Rare \\
\hline \multirow[t]{4}{*}{ Cheyletidae } & Cheletogenes sp. ${ }^{\mathrm{Pr}}$ & 0 & 3 & 0 & 3 & 0 & 0 & 0 & 0 & 0 & 1 & 3 & 0 & 10 & Acess \\
\hline & Imature ${ }^{\mathrm{Pr}}$ & 0 & 0 & 0 & 0 & 0 & 0 & 0 & 0 & 0 & 1 & 0 & 0 & 1 & Rare \\
\hline & Cheletomimus sp. ${ }^{\mathrm{Pr}}$ & 0 & 0 & 1 & 0 & 0 & 0 & 0 & 0 & 0 & 0 & 0 & 0 & 1 & Rare \\
\hline & Chiapacheylus sp. ${ }^{\mathrm{Pr}}$ & 6 & 24 & 10 & 15 & 23 & 1 & 5 & 2 & 9 & 4 & 1 & 17 & 117 & Const \\
\hline \multirow[t]{2}{*}{ Eriophyidae } & Calacarus sp. ${ }^{\mathrm{Ph}}$ & 332 & 450 & 425 & 634 & 130 & 93 & 834 & 1368 & 1330 & 1202 & 1273 & 491 & 8562 & Const \\
\hline & Mesalox sp. ${ }^{\mathrm{Ph}}$ & 0 & 0 & 0 & 0 & 57 & 0 & 78 & 0 & 10 & 0 & 6 & 0 & 151 & Acess \\
\hline Diptilomiopidae & Rhynacus aff. pamithus ${ }^{\mathrm{Ph}}$ & 5 & 142 & 64 & 62 & 15 & 5 & 1 & 6 & 182 & 85 & 21 & 18 & 606 & Const \\
\hline \multirow[t]{5}{*}{ Iolinidae } & Homeopronematus sp. ${ }^{\mathrm{Pr}}$ & 0 & 0 & 0 & 0 & 0 & 0 & 0 & 0 & 19 & 7 & 15 & 4 & 45 & Acess \\
\hline & Metapronematus sp. Pr? & 0 & 4 & 1 & 0 & 0 & 0 & 0 & 0 & 4 & 6 & 7 & 7 & 29 & Acess \\
\hline & Neopronematus sp. ${ }^{\mathrm{Pr} ?}$ & 3 & 6 & 3 & 2 & 8 & 2 & 7 & 4 & 8 & 6 & 4 & 0 & 53 & Const \\
\hline & Parapronematus sp. ${ }^{\mathrm{Pr}}$ ? & 0 & 2 & 0 & 0 & 5 & 0 & 1 & 0 & 4 & 2 & 0 & 0 & 14 & Acess \\
\hline & Pronematus sp. ${ }^{\mathrm{Pr}} ?$ & 16 & 45 & 14 & 79 & 125 & 137 & 239 & 218 & 50 & 59 & 51 & 34 & 1067 & Const \\
\hline \multirow[t]{6}{*}{ Phytoseiidae } & Euseius citrifolius ${ }^{\mathrm{Pr}}$ & 0 & 0 & 1 & 0 & 0 & 0 & 0 & 0 & 0 & 0 & 0 & 0 & 1 & Rare \\
\hline & Euseius sibelius ${ }^{\mathrm{Pr}}$ & 8 & 6 & 4 & 11 & 6 & 20 & 8 & 31 & 16 & 10 & 20 & 33 & 173 & Const \\
\hline & Galendromus $(G$.$) annectens { }^{\operatorname{Pr}}$ & 0 & 0 & 0 & 1 & 7 & 0 & 0 & 0 & 1 & 0 & 0 & 0 & 9 & Rare \\
\hline & Imature $^{\mathrm{Pr}}$ & 0 & 0 & 0 & 0 & 0 & 0 & 0 & 0 & 0 & 9 & 0 & 0 & 9 & Rare \\
\hline & Phytoseius guianensis ${ }^{\mathrm{Pr}}$ & 6 & 17 & 21 & 21 & 0 & 0 & 0 & 5 & 3 & 12 & 14 & 32 & 131 & Const \\
\hline & Phytoseius nahuatlensis ${ }^{\mathrm{Pr}}$ & 52 & 49 & 28 & 23 & 24 & 15 & 12 & 16 & 35 & 56 & 50 & 77 & 437 & Const \\
\hline \multirow[t]{3}{*}{ Stigmaeidae } & Agistemus sp. ${ }^{\mathrm{Pr}}$ & 6 & 2 & 2 & 2 & 1 & 0 & 1 & 6 & 3 & 0 & 2 & 3 & 28 & Const \\
\hline & Imature ${ }^{\mathrm{Pr}}$ & 0 & 0 & 0 & 0 & 0 & 0 & 0 & 0 & 0 & 1 & 0 & 0 & 1 & Rare \\
\hline & Zetzelia sp. ${ }^{\mathrm{Pr}}$ & 0 & 0 & 0 & 1 & 0 & 0 & 0 & 0 & 0 & 0 & 0 & 0 & 1 & Rare \\
\hline \multirow[t]{5}{*}{ Tarsonemidae } & Daidalotarsonemus sp. ${ }^{\mathrm{My}}$ & 4 & 5 & 3 & 1 & 0 & 0 & 0 & 0 & 0 & 0 & 18 & 48 & 79 & Acess \\
\hline & Fungitarsonemus sp. My & 1 & 0 & 0 & 0 & 0 & 0 & 0 & 0 & 0 & 0 & 0 & 0 & 1 & Rare \\
\hline & Imature ${ }^{\mathrm{My}}$ & 0 & 0 & 0 & 0 & 0 & 0 & 0 & 0 & 0 & 0 & 2 & 0 & 2 & Rare \\
\hline & Floridotarsonemus sp. ${ }^{\mathrm{My}}$ & 0 & 0 & 0 & 0 & 0 & 0 & 0 & 0 & 0 & 0 & 0 & 1 & 1 & Rare \\
\hline & Tarsonemus sp. ${ }^{\mathrm{My} ?}$ & 8 & 0 & 3 & 0 & 1 & 0 & 0 & 0 & 0 & 0 & 12 & 48 & 72 & Acess \\
\hline \multirow[t]{2}{*}{ Tenuipalpidae } & Brevipalpus phoenicis ${ }^{\mathrm{Ph}}$ & 0 & 0 & 0 & 1 & 0 & 0 & 0 & 0 & 1 & 0 & 0 & 0 & 2 & Rare \\
\hline & Imature? & 0 & 0 & 0 & 0 & 0 & 0 & 0 & 0 & 0 & 0 & 1 & 0 & 1 & Rare \\
\hline \multirow[t]{5}{*}{ Tetranychidae } & Atrichoproctus uncinatus ${ }^{\mathrm{Ph}}$ & 0 & 0 & 0 & 0 & 0 & 6 & 4 & 1 & 0 & 0 & 1 & 0 & 12 & Acess \\
\hline & Sonotetranychus angiopenis ${ }^{\mathrm{Ph}}$ & 0 & 10 & 6 & 48 & 11 & 1 & 4 & 0 & 9 & 1 & 1 & 0 & 91 & Const \\
\hline & Tetranychus mexicanus ${ }^{\mathrm{Ph}}$ & 1 & 13 & 2 & 0 & 0 & 0 & 0 & 2 & 0 & 0 & 0 & 0 & 18 & Rare \\
\hline & Allonychus reisi $^{\mathrm{Ph}}$ & 0 & 0 & 11 & 9 & 0 & 0 & 0 & 0 & 0 & 0 & 0 & 0 & 20 & Rare \\
\hline & Mononychellus aff. planki ${ }^{\mathrm{Ph}}$ & 0 & 0 & 0 & 0 & 0 & 0 & 0 & 0 & 0 & 0 & 1 & 0 & 1 & Rare \\
\hline \multirow[t]{4}{*}{ Tydeidae } & Lorryia formosa ${ }^{\mathrm{Ph} ?}$ & 26 & 136 & 60 & 199 & 106 & 8 & 0 & 0 & 0 & 0 & 2 & 0 & 537 & Const \\
\hline & Pretydeus sp. ${ }^{\mathrm{Ph}} ?$ & 0 & 0 & 0 & 0 & 0 & 0 & 0 & 0 & 0 & 0 & 0 & 1 & 1 & Rare \\
\hline & Pseudolorryia sp. ${ }^{\mathrm{Ph}}$ ? & 0 & 0 & 3 & 2 & 2 & 3 & 0 & 0 & 0 & 0 & 0 & 0 & 10 & Acess \\
\hline & Tydeus sp. ${ }^{\mathrm{Ph}}$ ? & 0 & 0 & 2 & 2 & 2 & 1 & 0 & 0 & 0 & 2 & 0 & 0 & 9 & Acess \\
\hline \multirow[t]{2}{*}{ Winterschimidtiidae } & Czenspinskia sp. ${ }^{\mathrm{My}}$ & 6 & 55 & 134 & 17 & 72 & 0 & 0 & 0 & 0 & 0 & 0 & 0 & 284 & Acess \\
\hline & Oulenzia sp. ${ }^{\mathrm{My}}$ & 3 & 3 & 1 & 22 & 7 & 0 & 0 & 0 & 0 & 0 & 2 & 1 & 39 & Const \\
\hline Total & & 483 & 973 & 799 & 1155 & 602 & 292 & 1194 & 1659 & 1684 & 1463 & 1509 & 816 & 12629 & \\
\hline
\end{tabular}

Feed habit: (Pr) Predators and generalist predators (Krantz 1978; McMurtry \& Croft 1997), (Ph) Phytophagous (Jeppson et al. 1975; Flechtmann 1975), (My) Mycophagous, (?) Feed habit unknown (Lindquist 1986; Krantz 1978; Gerson 1968 and Baker 1965).

overview, the effect of urban fragment over the most common species ranged according the dry or wet season.

In both fragments, Euseius sibelius (De Leon) and Pronematus sp. improved their abundances during the blooming period that was extended from September to February. (r $=0.768 ; \mathrm{p}=0.002$ and $\mathrm{r}=0.655 ; \mathrm{p}=0.020$, respectively).
The highest richness, diversity and evenness indexes were registered in the rural fragment (Tab. III). The dominant components curves were adjusted to the logarithmic models and were similar in the two areas (Fig. 4); nevertheless, the major dominance index was found in the urban fragment $(\mathrm{D}=$ $0.61)$ compared with the rural $(\mathrm{D}=0.46)$. 
Table III. Ecological parameters of the mite's community associated to Xylopia aromatica in the urban and rural fragments.

\begin{tabular}{lcr}
\hline \multicolumn{1}{c}{ Ecological Parameters } & Rural & Urban \\
\hline Richness (S) & 35 & 29 \\
Abundance & 12,610 & 14,727 \\
Dominance (D) & 0.46 & 0.61 \\
Diversity Shannon-Wiener (H') & 0.61 & 0.47 \\
Equitability (J) & 0.39 & 0.32 \\
\hline
\end{tabular}

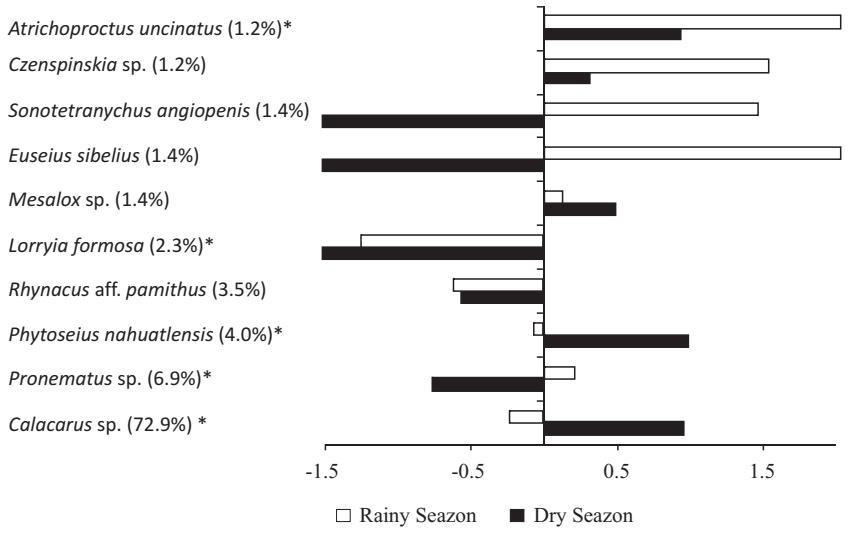

Fig. 3. Effects of the urban fragment over the abundance of species most abundant which corresponds to $96 \%$ of the total abundance of the community. The black bars represent the rainy season and the white ones, the dry season. * Species that showed significant different in the dry season.

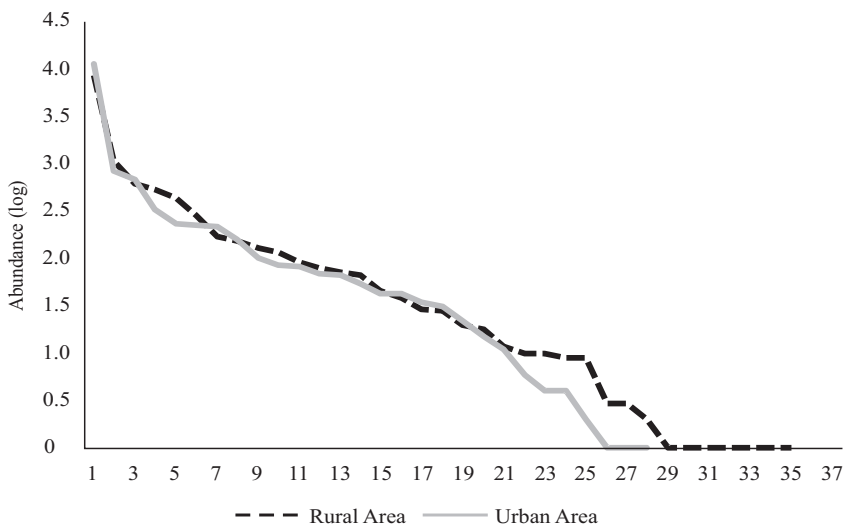

Fig. 4. Species abundance models of mites communities in the urban and rural fragments.

\section{DISCUSSION}

The small diversity and the higher dominance registered in both fragments were due to the abundance of two species of Eriophyoidea (superfamily that includes exclusively phytophagous species), Calacarus sp. and $R$. aff. pamithus. In the urban fragment, the infestation of those species was more intense, reaching $80 \%$ of the total mites sampled, while in the rural fragment corresponded to $70 \%$.

The ecological indexes obtained were similar to the ones reported by Daud \& Feres (2005), which compare the mite fauna of Mabea fistulifera Mart. (Euphorbiaceae) in urban and rural fragments, and by Feres et al. (2003) in Tabebuia roseo-alba (Ridl.) Sand (Bignoniaceae). In this manner, these works reflects patterns in the composition of mite community associated to native trees, with component dominance curves characterized by the high abundance of few phytophagous species.

Taxonomic reviews of mites associated with native vegetation in Neotropical region, have reported that just 30\% of the mites species could be identified as named species. The great number of morphospecies reflect the difficulty of identifying part of the species present, and because most of them are probably new to science too (Feres et al. 2005; Oliveira et al. 2005; Buosi et al. 2006; Demite et al. 2009).

Some studies (Flückiger \& Braun 1999; Agrell et al. 2006) pointed out that plants in urban environment can present their physiology altered due to being submitted to stress conditions, a greater exposure to atmospheric pollutants, such as carbon dioxide and monoxide released by vehicles and other anthropic activities. Larcher (2000) and White (1984) reported that high atmospheric concentration of $\mathrm{CO}_{2}, \mathrm{CO}$ and NO could increase the availability of free amino acids rare in the leaves. Works have reported that plants close to highways and urban areas suffer higher herbivory rates and mites infestations than others most distant (White 1984; Daud \& Feres 2005; Christie \& Hochuli 2005).

In this manner, the urban environment might have provide favorable conditions for the increasing of phytophagous mites populations, especially throughout the dry season, probably when the plants were also submitted to hydric stress. In the same period in the urban fragment, the abundance of Eriophyoidea mites was twice higher than the rural fragment. As a whole, the abundance of other phytophagous species was also superior in the urban fragment.

Therefore it is possible to infer that urban fragment had positive effects over the abundance of phytophagous species and negative over the predators. The abundance of Calacarus sp. was superior in the urban area, whereas the Pronematus $\mathrm{sp}$. (predator) was greater in the rural area. Besides the stress conditions, the environmental heterogeneity is another factor to be considered too, according to Begon et al. (2007), the arthropods richness is related directly with the vegetal diversity of the environment where they are inserted. The richness as well as the diversity is higher in natural ecosystems; whereas in environments with anthropic interference, the structure of the community as a whole presents alterations, having a tendency for losing the diversity and reducing the species richness (Odum 1988).

Euseius species are characterized by the diversified feeding habits, being able to feed themselves with prey, pollen, exudates or even fungus. According to McMurtry \& Croft (1997) and Croft et al. (2004), mites like Euseius are classified as predators type IV, whose diet includes pollen, and secondly, other mites as their eggs. Similarly, Pronematus species are able to feed as pollen and as prey too (De Vis et al. 2006). The greater environmental heterogeneity in the rural 
fragment could have provide a wide diet variety for the predators mites Euseius and Pronematus, besides others favorable resources like refuges and micro-habitat. Furthermore, the overpopulation of these species in the blooming period pointed out the importance of pollen as part of their diets. Such conditions could be favorable to the increased of the abundance of these species in the rural fragment.

Therefore, it can be concluded that $X$. aromatica can shelter a higher diversity of mites when it is located in a well preserved ecosystem, since the higher diversity available allows the settlement of richer and diverse mite fauna. On the other hand if, this vegetal species is inserted in a homogeneous and impacted fragment and submitted to a physiological stressing condition, an increase of phytophagous species will occur with a loss of richness and diversity.

\section{ACKNOWLEDGEMENTS}

We are thankful to Dr. Rodrigo D. Daud (Universidade Estadual Paulista - UNESP, São José do Rio Preto, São Paulo, Brazil) and MSc. Getulio Minoru Tanaka Junior (Universidade de São Paulo, Ribeirão Preto, São Paulo, Brazil) to the valuable suggestions and critical review of the text, and Prof. Dr. Antonio Carlos Lofego (UNESP, São José do Rio Preto, São Paulo, Brazil) for the assistance in the identification of Tarsonemidae mites. This work was supported by PIBIC/CNPq (FMN, proc. 119012/2007-3), and FAPESP (PRD, proc. 2006/55725-6).

\section{REFERENCES}

Agrell, J.; P. Anderson; W. Oleszek; A. Stochmal \& C. Agrell. 2006. Elevated $\mathrm{CO}_{2}$ levels and herbivore damage alter host plant preferences. Oikos 112: $63-72$.

Altieri, M. A.; E. N. Silva \& C. I. Nicholls. 2003. O papel da biodiversidade no manejo de pragas. Ribeirão Preto, Holos Editora, $226 \mathrm{p}$

Baker, E. W. 1965. A review of the genera of the family Tydeidae (Acarina). Advances in Acarolology 2: 95-133.

Barcha, S. F. \& F. M. Arid. 1971. Estudo da evapotranspiração na região Norte Ocidental do Estado de São Paulo. Revista Científica da Faculdade de Ciências e Letras de Votuporanga 1: 94-122.

Begon, M.; C. R. Townsend \& J. L. Harper. 2007. Ecologia: de indivíduos a ecossistemas. $4^{\mathrm{a}} \mathrm{Ed}$, Porto Alegre, Artmed, $740 \mathrm{p}$.

Buosi, R.; R. J. F. Feres; A. R. Oliveira; A. C. Lofego \& F. A. Hernandes. 2006. Ácaros plantícolas (Acari) da "Estação Ecológica de Paulo de Faria”, Estado de São Paulo, Brasil. Biota Neotropica 6. Available from: http://www.biotaneotropica.org.br/v6n1/pt/abstract?article+ bn02006012006. (Accessed 10 October 2008).

Christie, F. J. \& D. F. Hochuli. 2005. Elevated levels of herbivory in urban landscapes: are declines in tree health more than an edge effect? Ecology and Society 10: 10. Available from: http://www.ecologyandsociety.org/ vol10/iss1/art10/(Accessed 06 August 2008).

Croft, B. A.; J. S. Blackwood \& J. A. McMurtry. 2004. Classifying lifestyle types of phytoseiid mites: diagnostic traits. Experimental and Applied Acarology 33: 247-260.

Daud, R. D. \& R. J. F. Feres. 2005. Diversidade e flutuação populacional de ácaros (Acari) em Mabea fistulifera Mart. (Euphorbiaceae) de dois fragmentos de mata estacional semidecídua em São José do Rio Preto, SP. Neotropical Entomology 34: 191-201.

De Vis, R. M. J.; G. J. de Moraes \& M. R. Bellini. 2006. Initial screening of little known predatory mites in Brazil as potential pest control agents. Experimental and Applied Acarology 39: 115-125.
Demite, P. R. \& R. J. F. Feres. 2005. Influência de vegetação vizinha na distribuição de ácaros em seringal (Hevea brasiliensis Muell. Arg., Euphorbiaceae) em São José do Rio Preto, SP. Neotropical Entomology 34: 829-836.

Demite, P. R. \& R. J. F. Feres. 2008. Inûuência de fragmentos de Cerrado na distribuição de ácaros em seringal. Neotropical Entomology 37: 196-204.

Demite, P. R.; R. J. F. Feres; A. C. Lofego \& A. R. Oliveira. 2009. Plant inhabiting mites (Acari) from the Cerrado biome of Mato Grosso State, Brazil. Zootaxa 2061: 45-60.

Feres, R. J. F.; M. R. Bellini \& D. C. Rossa-Feres. 2003. Ocorrência e diversidade de ácaros (Acari, Arachnida) associados a Tabebuia roseoalba (Ridl.) Sand (Bignoniaceae), no município de São José do Rio Preto, São Paulo, Brasil. Revista Brasileira de Zoologia 20: 373-378.

Feres, R. J. F.; A. C. Lofego \& A. R. Oliveira. 2005. Ácaros plantícolas (Acari) da "Estação Ecológica do Noroeste Paulista", Estado de São Paulo, Brasil. Biota Neotropica 5: 43-56.

Feres, R. J. F.; R. Buosi; R. D. Daud \& P. R. Demite. 2007. Padrões ecológicos da comunidade de ácaros em euforbiáceas de um fragmento de mata Estacional Semidecidual, no Estado de São Paulo. Biota Neotropica 7. Available from: http://www.biotaneotropica.org.br/v7n2/ pt/abstract?article+bn04907022007 (Accessed 15 October 2008).

Flechtmann, C. H. W. 1975. Elementos de acarologia. São Paulo, Livraria Nobel S. A., 344 p.

Flückiger, W. \& S. Braun. 1999. Stress factors of urban trees and their relevance for vigour and predisposition for parasite attacks. Acta Horticulturae 496: 325-334.

Gerson, U. 1968. Five tydeid mites from Israel (Acarina: Prostigmata). Israel Journal of Zoology 17: 191-198.

Krantz, G. W. 1978. A manual of acarology. $2^{\text {nd }}$ Ed. Corvallis, Oregon State University Book Stores, 509 p.

Krebs, C. J. 1999. Ecological methodology. $2^{\text {nd }}$ ed. Benjamin Cummings, Menlo Park, California. 620 p.

Kronka, F. J. N; C. K. Matsukuma; M. A. Nalon; I. H. Delcali; M. Rossi; I. F. A. Mattos; M. S. Shin-Ike \& A. A. S. Pontinhas. 1993. Inventário florestal do Estado de São Paulo. São Paulo, Instituto Florestal, 199 p.

Jeppson, L. R.; H. H. Keifer \& E. W. Baker. 1975. Mites injurious to economic plants. Berkeley, University of California Press, 641p.

Larcher, W. 2000. Ecofisiologia vegetal. São Carlos, Rima Artes e Textos, $531 \mathrm{p}$.

Lindquist, E. E. 1986. The world genera of Tarsonemidae (Acari: Heterostigmata): a morphological, phylogenetic and systematic revision, with a reclassification of family-group taxa in the Heterostigmata. Memoirs of the Entomological Society of Canada 136: 1-517.

Lorenzi, H. 2000. Árvores brasileiras: manual de identificação e cultivo de plantas arbóreas nativas do Brasil. vol. 1, Nova Odessa, Instituto Plantarum, $367 \mathrm{p}$.

Magurran, A. E. 1988. Ecological diversity and its measurement. Cambridge, University Press, 179 p.

McAleece, N.; P. J. D. Lambshead \& G. L. J. Paterson. 1997. BioDiversity Professional statistical analysis software Available from: http:// www.sams.ac.uk/research/software/bdpro.zip/view. (Accessed 16 July 2007).

McMurtry, J. A. \& B. A. Croft. 1997. Life-styles of phytoseiid mites and their roles in biological control. Annual Review of Entomology 42: 291-321.

Miranda-Mello, A. A.; F. R. Martins \& F. A. M. dos Santos. 2007. Estrutura populacional de Xylopia aromatica (Lam.) Mart. e Roupala montana Aubl. em fragmentos de cerrado no Estado de São Paulo. Revista Brasileira de Botânica 30: 501-507. Available from: http://www.scielo.br/ scielo.php?script $=$ sci_arttext\&pid $=$ S0100-84042007000300014 (Accessed 23 September 2008).

Odum, E. P. 1988. Ecologia. Rio de Janeiro, Guanabara Koogan, 434 p.

Oliveira, A. R.; Norton, R. A. \& G. J. de Moraes. 2005. Edaphic and plant inhabiting oribatid mites (Acari: Oribatida) from Cerrado and Mata Atlântica ecosystems in the State of São Paulo, southeast Brazil. Zootaxa 1049: 49-68. 
Olkin, I. 1995. Statistical and theoretical considerations in meta-analysis. Journal of Clinical Epidemiology 48: 133-146.

Rossa-Feres, D. C. \& J. Jim. 2001. Similaridade do sítio de vocalização em uma comunidade de anfíbios anuros na região noroeste do Estado de São Paulo, Brasil. Revista Brasileira de Zoologia 18: 439-454.

Silveira-Neto, S.; O. Nakano; D. Barbin \& N. A. V. Nova. 1976. Manual de ecologia dos insetos. São Paulo, Agronômica Ceres, 419 p.

SMA/IF (Secretaria do Meio Ambiente/Instituto Florestal). 2005. Inventá- rio florestal da vegetação natural do Estado de São Paulo. São Paulo, Imprensa Oficial do Estado de São Paulo, 199 p.

Viana, V. M. \& L. A. F. V. Pinheiro. 1998. Conservação da biodiversidade de fragmentos florestais. Série Técnica IPEF 12: 25-42.

White, T. C. R. 1984. The abundance of invertebrate herbivores in relation to the availability of nitrogen in stressed food plants. Oecologia 63: 90-105.

Zar, J. H. 1999. Biostatistical analysis. $4^{\text {th }}$ ed., New Jersey, Prentice-Hall, Inc. $633 \mathrm{p}$. 